\title{
KARAKTERISASI BAKTERI PATOGEN PENYEBAB LAYU PADA TANAMAN BAWANG MERAH (Allium ascalonicum L.)
}

\author{
${ }^{1)}$ Intan Fuji Arriani, ${ }^{2)}$ Abdul Latief Abadi, ${ }^{3)}$ Luqman Qurata Aini \\ Fakultas Pertanian Universitas Brawijaya \\ Fakultas Pertanian Universitas Brawijaya Jl. Veteran, Kota Malang, Jawa Timur 65145 \\ Email: ${ }^{1)}$ Intanfuji485@gmail.com
}

\begin{abstract}
Shallot (Allium ascalonicum L.) is one of the vegetable commodities in the form of tubers that have a high economic value. The development of shallot cultivation in Indonesia often experiences obstacles, one of which is an obstacle in the process of shallot cultivation, namely the attack of Plant Disturbing Organisms (OPT). Information about diseases caused by pathogenic bacteria is still very limited. This study aims to determine the symptoms and identification of pathogenic bacteria that cause wilt in shallots. Bacterial isolation was carried out using Nutrient Agar (NA) media and 36 bacterial isolates were collected from shallots. Bacterial isolates were then tested for pathogenicity to determine the ability of bacteria to cause wilt disease in shallots. The results of isolation obtained 10 bacterial isolates that can show symptoms on red onions namely wilted leaves, yellow and soft rotten tubers. Four isolates including positive can show hypersensitivity symptoms, namely M11, N20, N17 and N14. Based on the identification of bacteria in physiology showed 2 groups of different isolates. Biochemical test results of Isolate M11, N20 and show species suspected of B. cepacia. $\mathrm{N} 3$ and N14 isolates are suspected to be E. carotavora subsp. carotavora. The bacterial isolates N7, N17, P5 and P7 were suspected to be E. carotavora subsp. betavasculorum. The isolate of N4 bacteria is suspected to be E. cacticida.
\end{abstract}

\section{Keywords : Wilt, soft rot, B. cepacia, B. seminalis, E. carotavora subsp. carotavora, E. carotavora subsp. betavasculorumand E. cacticida.}

\section{PENDAHULUAN}

Bawang merah (Allium ascalonicumL.) merupakan salah satu komoditas sayuran berupa umbi yang memiliki nilai ekonomis cukup tinggi. Di Indonesia sentra produksi bawang merah pada periode 2010-2014 yaitu Jawa Tengah, Jawa Timur, Jawa Barat dan Nusa Tenggara Barat. Empat sentra produksi tersebut memiliki kontribusi sebesar 86,24 $\%$ terhadap rata-rata produksi bawang merah di Indonesia (Kementrian Pertanian, 2015). Pengembangan budidaya bawang merah di Indonesia sering kali mengalami kendala, salah satu yang menjadi kendala dalam proses budidaya bawang merah yaitu serangan Organisme Pengganggu Tanaman (OPT). Sejauh ini penelitian penyakit bawang merah yang disebabkan oleh jamur dan virus telahbanyakdilaporkan, namun informasi mengenai penyakit yang disebabkan oleh bakteri pathogen masih sangat terbatas. Beberapa jenis bakteri pathogen dapat menimbulkan penyakit pada tanaman. Bakteri yang pernah dilaporkan menyerang tanaman bawang merah di Indonesia adalah Pseudomonas allicola yang menyebabkan busuk bakteri di Jawa. Bawang merah yang dibudidayakan di Jawa dan Sumatra terinfeksi oleh Pectobacterium carotovorum (syn.Erwinia carotovora) yang menyebabkan busuk lunak. Di Jawa dan Sumatera dikenal sebagai busuk umbi yang disebabkan oleh bakteri Erwinia carotavorapv. carotavora. Infeksi bakteri tersebut dapat 
terjadi pada saat tanaman mendekati kemasakan, namun kerugian akibat bakteri ini lebih banyak terjadi pada penyimpanan (Semangun, 1994).

Bakteri Pantoeaananatis juga dilaporkan sebagai patogen yang diduga menyebabkan penyakit layu. Gejala yang ditimbulkanya itu daun mengering, terdapat garis putih pada daun, semakin lama warna menjadi gelap kecoklatan selain itu umbi pada bawang merah membusuk dan tanaman menjadi layu (Gitaitiset al., 2002). Patogen lain yang pernah dilaporkan menjadi penyebab gejala layu pada tanaman bawang adalah genus Burkholderia yang dicirikan dengan gejala water soaking (luka kebasahan) dan masesari, setelah serangan semakin lama tanaman akan menunjukkan gejala layu (Asselin et al., 2016). Beragamnya jenis bakteri patogen yang dapat menyebabkan penyakit pada tanaman bawang merah, menunjukkan tingginya ancaman kegagalan produksi tanaman bawang merah. Oleh karenanya perlu dilakukan kajian yang dapat mengidentifikasi penyebab dari penyakit yang muncul khususnya pada tanaman bawang merah, sehingga diharapkan dapat disusun solusi penanggulangannya kedepan.

\section{METODE PENELITIAN}

\section{Pengambilan Sampel}

Pengambilan sampel bawang merah dilakukan di pertanaman bawang merah yang terletak di wilayah Malang. Probolinggo dan Nganjuk. Sampel tanaman bawang merah diambil dilahan yang terindikasi umbi bawang merah membusuk dan atau tanaman layu.

\section{Isolasi patogen}

Metode isolasi yang digunakan diadopsi dari penelitian Kharayat dan signh (2015) yaitu dengan cara mengambil umbi yang terindikasi penyakit layu dipotong 0-2 $\mathrm{cm}$, kemudian dicuci diair mengalir. Umbi didesinfeksi dengan alkohol $75 \%$ selama 1 menit dan aquades steril selama 1 menit. Sampel umbi yang sakit ditumbuhkan pada media NA dan diinkubasi selama 24 jam sampai pathogen tumbuh, kemudian dipurifikasi pada media NA yang baru untuk mendapatkan kultur murni.

\section{Uji postulat Koch's}

Tanaman bawang merah yang menunjukkan gejala sakit diisolasi dan ditumbuhkan pada media NA. Umbi bawang merah yang menunjukkan gejala sakit di sterilisasi dengan alkohol $75 \%$ selama 1 menit. Sampel direndam pada air steril sebanyak 2 kali selama 30 detik. Selanjutnya ditumbuhkan pada media NA dan diinkubasi pada suhu ruang selama 24 jam. Selanjutnya menyuntikkan suspense bakteri patogen pada umbi bawang merah dan diamati gejala busuk pada umbi dan layu pada tanaman.

\section{Uji Patogenesitas}

Uji pathogenesitas mengacu pada Schaad et al. (2001) ; Kharayat dan signh (2015) yang telah dimodifikasi yaitu dengan menyiapkan tanaman kontrol dan non kontrol. Tanaman bawang merah ditumbuhkan pada polybag yang telah berisi media tanam tanah dan kompos.Suspensi bakteri disiapkan dengan kerapatan $10^{9} \mathrm{cfu} / \mathrm{ml}$. Suspensi bakteri diinjeksikan pada batang tanaman bawang merah non kontrol, sedangkan tanaman control diinjeksikan dengan aquades steril.

\section{Uji Hipersensitif}

Uji hipersensitif merupakan uji yang dilakukan untuk mengetahui sifat patogenik suatu bakteri.Metode uji hipersensitif mengacu pada Schaad et al., (2001). Bakteri ditumbuhkan pada media NA dan diinkubasi selama 1-2 hari. Bakteri dipanen kerapatan 
$10^{9} \mathrm{cfu} / \mathrm{ml}$ dengan aquades steril kemudian suspensi bakteri diinokulasikan pada bagian tulang daun tembakau sebanyak $1 \mathrm{ml}$. Reaksi hipersensitif akan menunjukkan gejala nekrotik pada bagian daun. Perkembangan gejala yang ditimbulkan diamati selama 24-48 jam.

\section{Identifikasi genus}

\section{Karakterisasi Morfologi}

Pengamatan ini dilakukan untuk mengetahui morfologi koloni bakteri agar bias diidentifikasi secara morfologi. Pengamatan morfologi koloni meliputi bentuk, ukuran, tepi, warna, dan permukaan koloni. Bakteri yang diamati ditumbuhkan pada media NA dan berumur 48 jam.

\section{Karakterisasi Fisiologi}

Karakterisasi ini bertujuan untuk menentukan genus isolate bakteri. Metode yang digunakan berdasarkan Schaad et al. (2001). Karakterisasi ini meliputi uji Gram dengan kelarutan $\mathrm{KOH} 3 \%$ dan pewarnaan Gram, uji Oksidatif- Fermentatif, uji produksi pigmen fluorescent dengan menggunakan media King's B, dan terakhir uji pertumbuhan pada media Yeast Extract-Dextrose- Carbonat (YDC).

\section{Karakterisasi Biokimia}

Karakterisasi ini bertujuan untuk menentukan spesies isolate bakteri. Metode yang digunakan berdasarkan Schaad et al. (2001) meliputi pertumbuhan pada suhu $40^{\circ} \mathrm{C}$, pertumbuhan pada $\mathrm{pH} 4,8$ dan 9 , pertumbuhan pada $\mathrm{NaCl} 3 \%$, pencairan gelatin, hidrolisis arginine, hidrolisispati, pertumbuhan pada suhu $37^{\circ} \mathrm{C}$, produksi indol, reduksi gula oleh sukrosa, aktifitasfosfat, sensifitas terhadap eritromicin, produksi asam dari sumber karbon laktosa.

\section{HASIL DAN PEMBAHASAN}

\section{Deskripsi gejala penyakit}

Gejala penyakit layu yang ditemukan pada pertanaman bawang merah di Malang, Nganjuk dan Probolinggo menunjukkan gejala berupa layu daun, daun klorosis, daun bewarna kuning dan busuk lunak pada umbi. Tingkat serangan lanjut, daun mengering dan mengalami kematian. Gejala tersebut sesuai dengan deskripsi penyakit layu menurut Semangun (2007), bakteri patogen yang menyebabkan layu pada tanaman bawang merah memiliki gejala busuk lunak pada umbi dan tanaman layu.

\section{Isolasi, uji patogenisitas dan postulat Koch's penyakit layu bakteri pada tanaman bawang merah}

Pengambilan sampel tanaman layu dilakukan di pertanaman bawang merah Malang, Nganjuk dan Probolinggo. Hasil isolasi bakteri didapatkan 36 isolat bakteri yang tumbuh pada media NA diumur $48 \mathrm{jam}$. Namun, dari hasil isolasi hanya 10 isolat bakteri yang dapat menunjukkan gejala layu yaitu isolat M11 dari Malang, isolat N8, N20, N3, N4, N7, N14, N17 dari Nganjuk dan isolat P5, P7 dari Probolinggo. Koloni yang diperolehbervariasi, isolat M11, N20 dan N8 memiliki warna koloni kuning dan berbentuk bulat, sedangkan isolat N3, N4, N7, N14, N17, P5 dan P7 memiliki warna koloni putih dan berbentuk bulat.

Hasil uji patogenesitas menunjukkan semua isolate bakteri menunjukkan gejala yang sama atau tidak spesifik yaitu daun layu, daun klorosis, berwarna kuning, umbi 
busuk lunak. Pengujian postulat Koch's dilakukan dengan mengisolasi kembali bagian tanaman yang menunjukkan gejala layu dan busuk umbi dalam media NA. Hasil reisolasi bakteri mempunyai warna dan bentuk koloni yang sama.

\section{Uji Hipersensitif}

Uji hipersensitif dilakukan untuk mengetahui apakah suatu bakteri bersifat pathogen bagi suatu tanaman atau tidak. Isolat bakteri yang dilakukan uji menunjukkan respon gejala hipersensitif yang berbeda-beda. Isolat M11 dan N20 menimbulkan gejala hipersensistif pada 2 hsi, sedangkan isolat N17 dan N14 menimbulkan gejala hipersensitif pada 6 hsi.Gejala yang ditimbulkan pada area daun tembakau yang diinokulasi dengan bakteri patogen, yaitu gejala water soak (basah), selanjutnya daun mengalami klorosis (berwarna kuning) dan nekrosis.

\section{Karakteristik Fisiologi Bakteri Penyebab Layu Bakteri Pada Tanaman Bawang Merah}

Hasil uji Gram diketahui bakteri bersifat negatif dan berbentuk basil, hal tersebut diketahui pada uji KOH $3 \%$ isolate bakteri M11, N8, N20, N3, N4, N7, N14, N17, P5, P7 berlendir ketika diangkat dengan jarumose dan pada perwarnaan Gram menunjukan warna merah berbentuk basil. Berdasarkan hasil uji isolate bakteri M11, N8 dan N20 memiliki karakteristik yaitu bersifat oksidatif, koloni berwarna kuning pada media YDC, tidak mengeluarkan pigmen fluoresen dan tidak dapat tumbuh pada media D1M agar (Tabel 1). Menurut Schaad et al. (2001) bakteri yang memiliki karakteristik diatas diduga sebagai genus Burkholderia. Sedangkani solat bakteri N3, N4, N7, N14, N17, P5 dan P7 memiliki karakteristik yaitu bakteri bersifat fermentatif dan koloni berwarna putih pada media YDC (Tabel 1). Berdasarkan karakteristik tersebut menurut Shaadet al. (2001) isolat M11, N8 dan N20 diduga genus Burkholderia dan isolat N3, N4, N7, N14, N17, P5 dan P7 diduga genus Erwinia.

\section{Karakteristik biokimia bakteri penyebab layu bakteri pada tanaman bawang merah}

Berdasarkan uji biokimia menunjukkan isolate bakteri M11, N8 dan N20 memliki karakteristik yaitu mampu tumbuh pada suhu $40^{\circ} \mathrm{C}, \mathrm{pH} 4,8$ dan 9 . Pada media $3 \% \mathrm{NaCl}$ bakteri tersebut dapat tumbuh sekitar $25-75 \%$, tidak menghidrolisis gelatin, menghidrolisis arginine dan tidak menghidrolisispati (Tabel 2). Beberapa karakteristik tersebut diatas sesuai dengan karakter bakteri yang diduga spesiesB. cepacia(Schaad et al., 2001).

Hasil uji biokimia isolate bakteri N3, N14 dan P7 memiliki karakteristik dapat tumbuh pada suhu $37^{\circ} \mathrm{C}$, tidak memproduksi indol, tidak menghasilkan aktifitas fosfat, tidak sensitif terhadap eritromisin, tidak dapat mereduksi gula oleh sukrosa. Sedangkan isolat N7, N17 dan P5 bersifat dapat tumbuh pada suhu $37^{\circ} \mathrm{C}$, tidak memproduksi indol, tidak sensitive terhadap eritromicin. Isolat P5 mempunyai karakteristik berbeda yaitu tidak menghasilkan aktifitas fosfat dan tidak dapat memproduksi karbon dari laktosa. Selanjutnya isolat N4 memiliki karakteristik dapat tumbuh pada suhu $37^{\circ} \mathrm{C}$, tidak memproduksi indol, mampu menghasilkan aktifitas fosfat, tidak sensitive terhadap eritromisin, tidak dapat mereduksi gula oleh sukrosa dan tidak dapat memproduksi karbon dari laktosa (Tabel 3). Mengacu pada Schaad et al. (2001), isolat N3, N14, P7 memiliki kemiripan karakteristik terhadap spesies E. carotavora subsp. carotavora, isolat N7, N17 dan P5 memiliki kemiripan karakteristik spesies E. carotavora subsp. Betavasculorum dan isolat N4 memiliki kemiripan karakteristik spesies E. cacticida. 
Copyright@UNISBA Blitar, http://ejournal.unisbablitar.ac.id/index.php/viabel

Intan Fuji Arriani, Abdul Latief Abadi \& Luqman Qurata Aini, 2020. Karakterisasi Bakteri

Patogen Penyebab Layu Pada Tanaman Bawang Merah (Allium ascalonicum L.). Journal Viabel Pertanian. (2020), 14(1)69-75

Tabel 1. Karakterisasi fisiologi isolate bakteri penyebab layu bakteri pada tanaman bawang merah

\begin{tabular}{lccccc}
\hline \multirow{2}{*}{$\begin{array}{l}\text { Kode } \\
\text { isolat }\end{array}$} & Uji Gram & $\begin{array}{l}\text { Tesoksidatif }- \\
\text { fermentative }\end{array}$ & $\begin{array}{l}\text { Koloni } \\
\text { kuning di } \\
\text { media YDC }\end{array}$ & $\begin{array}{l}\text { Pigmen } \\
\text { fluoeresen }\end{array}$ & $\begin{array}{l}\text { Pertumbuhan di } \\
\text { D1M agar }\end{array}$ \\
\cline { 2 - 6 } M11 & - & - & + & - & - \\
N20 & - & - & + & - & - \\
N8 & - & - & + & - & TD \\
N3 & - & + & - & TD & TD \\
N4 & - & + & - & TD & TD \\
N7 & - & + & - & TD & TD \\
N14 & - & + & - & TD & TD \\
N17 & - & + & - & TD & TD \\
P5 & - & + & - & TD & TD \\
P7 & - & + &
\end{tabular}

Keterangan : (-) reaksinegatif, (+) reaksipositif, (TD) tidak diuji.

Tabel 2. Hasil uji beberapa isolate bakteri penyebab layu bakteri pada bawang merah untuk genus burkholderia

\begin{tabular}{lllllllll}
\hline \multicolumn{1}{c}{ Test } & \multicolumn{7}{c}{ Isolat } \\
\cline { 2 - 8 } & N3 & N4 & N7 & N14 & N17 & P5 & P7 \\
\hline Pertumbuhan pada $370 \mathrm{C}$ & + & + & + & + & + & + & + \\
Produksi Indol & - & - & - & - & - & - & - \\
Reduksi gula oleh sukrosa & - & - & + & - & + & + & - \\
Aktifitas fosfat & - & + & - & - & + & + & - \\
Sensifitas terhadap eritromisin & - & - & - & - & - & - & - \\
Produksi asam dari sumber karbon : & & & & & & & \\
Lactose & & & & & & & \\
\end{tabular}

Keterangan : (-) reaksi negatif, (+) reaksipositif, (V) $21-71 \%$ positif.

Tabel 3. Hasil uji biokimia beberapa isolate bakteri penyebab layu bakteri pada bawang merah untuk genus Erwinia.

\begin{tabular}{|c|c|c|c|}
\hline Tes & M11 & N8 & $\mathrm{N} 20$ \\
\hline Pertumbuhan pada 400C & + & + & + \\
\hline Pertumbuhan $\mathrm{pH} 4$ & + & + & + \\
\hline Pertumbuhan $\mathrm{pH} 8$ & + & + & + \\
\hline Pertumbuhan $\mathrm{pH} 9$ & - & + & + \\
\hline Pertumbuhan pada $3 \% \mathrm{NaCl}$ & V & V & V \\
\hline Pencairan gelatin & - & - & - \\
\hline Hidrolisis arginine & + & + & + \\
\hline Hidrolisis pati & - & - & - \\
\hline
\end{tabular}

Keterangan : (-) reaksi negatif, (+) reaksi positif, (V) $21-71 \%$ positif. 
Dari hasil penelitian menunjukkan bahwa bakteri B. cepacia ditemukan diwilayah Malang dan Nganjuk dengan gejala penyakit yang sama. Sejauh ini bakteri B. cepacia belum pernah dilaporkan menyerang tanaman bawang merah di Indonesia. Bakteri $B$. cepacia banyak dilaporkan menyerang pada tanaman bawang Bombay di New York, Amerika Serikat (Govanet al., 1996). Selain Amerika Serikat, bakteri B. cepacia juga dilaporkan menyerang tanaman bawang Bombay di Jepang (Sotokawa dan Takikawa, 2004).

Bakteri pathogen E. carotavora ditemukan diwilayah Nganjuk dan Probolinggo. Gejala yang ditimbulkan yaitu sama atau dispesifik. Bakteri E. carotavora sebelumnya pernah dilaporkan oleh Semangun (2007) penyebab busuk lunak pada tanaman bawang merah di Jawa dan Sumatera. Gejala yang ditimbulkan yaitu umbi mengalami busuk lunak keatas dan tanaman layu. Selain itu Schwartz dan Mohan (2008) menjelaskan bahwa bakteri E. carotavora dapat menyebabkan busuk lunak pada tanaman dari genus Aliium atau bawang-bawangan. Sedangkan bakteri E. Cacticida hanya ditemukan di Nganjuk, bakteri tersebut belum pernah dilaporkan dapat menyebabkan layu dan busuk lunak di tanaman bawang merah. Menurut Hildago et al. (2004) bakteri E..cacticida masih dalam kelompok Entero bacteria penyebab penyakit busuk lunak.

Penelitian sebelumnya Putri, Pramhasari (2015) melaporkan adanya keberadaan pathogen dari kelompok Entero bacteria sebagai pathogen penyebab busuk lunak dan menimbulkan gejala layu di Jawa. Penelitian ini menunjukkan adanya asosiasi bakteri $B$. cepacia, E. carotavora dan E. cacticida dengan tanaman bawang merah di Indonesia.

\section{KESIMPULAN}

Terdapat 10 isolat bakteri yang dapat menimbulkan gejala layu pada tanaman bawang merah yaitu isolat bakteri M11 berasal dari Malang, isolat bakteri N3, N4, N7, N8, N14, N17, N20 berasaldari Nganjuk dan isolate bakteri P5 dan P7 berasal dari Probolinggo. Gejala yang ditimbulkan antar isolat tidak spesifik atau gejala yang ditunjukkan sama.

Hasil identifikasi fisiologi dan biokimia yang telah dilakukan menunjukkan bahwa isolate bakteri M11, N8, N20 adalah B. cepacia. Isolat N3 dan N14 adalah $E$. carotavora subsp. carotavora. Isolatbakteri N7, N17, P5 dan P7 adalah E. carotavora subsp. betavasculorum. Isolat bakteri N4 adalah E. cacticida. 


\section{DAFTAR PUSTAKA}

Asselin, J.A.E., J.M. Bonasera and S.V. Beer. 2016. PCR Primers for Detection of Pantoeaananatis, Burkholderia spp., and Enterobacter sp. from Onion. Plant Disease. 100 (4) : 836.

Bhat, K.A., S.D. Masoodi.,N.A. Bhat., M. Ahmad., M.Y. Zargar., S.A Mir and M.A. Bhat. 2010. Studies on the Effect of Temperature on the Development of Soft Rot of Cabbage (Brassica oleracea var. capitata) caused by Erwinia carotavorasubps. carotavora. J of Phtypathol. 2 (2) : 64-67.

Chen, Y.S., S.C.Chen.,C.M. Kao and Y.L. Chen. 2003. Effects of Soil pH, Temperature and Water Content on the Growth of Burkholderia pseudomallei. (Online).Diaksestangga 15 November 2018.

Gitaitis, R., R. Walcott., S. Culpepper., H. Sanders., L. Zolobowska and D. Langston. 2002. Recovery of Pantoeaananatis, causal Agent of Center Rot of Onion, from Weeds and Crops in Georgia, USA. J. Crop Prot. 21 : 983-989.

Govan, J.R.W., J.E. Hughes and P. Vandamme. 1996. Burkholderiacepacia : Medical, Taxonomic and Ecological Issues. J. Med. Micobiol. 45 : 396.

KementrianPertanian. 2005. Outlook Bawang Merah. Pusat Data dan SistemInformasiPertanian. Jakarta. 